\title{
Constructing EFL Classroom Interactional Knowledge in Teacher Education
}

\author{
Hongmei $\mathrm{Zhu}^{1}$ \\ ${ }^{1}$ College of International Studies, Southwest University, Chongqing, China \\ Correspondence: College of International Studies, Southwest University, Chongqing, China. Tel: \\ 86-153-2030-0726. E-mail: zhm66676@163.com
}

$\begin{array}{lc}\text { Received: October 2, } 2013 & \text { Accepted: November 4, } 2013 \quad \text { Online Published: November 24, } 2013 \\ \text { doi:10.5539/ijel.v3n6p119 } & \text { URL: http://dx.doi.org/10.5539/ijel.v3n6p119 }\end{array}$

\begin{abstract}
This article aimed at constructing the knowledge of EFL classroom interaction rooted in reflective teacher education. Based on the literature of the nature of knowledge, the knowledge bases of EFL teaching and the different views on EFL classroom interaction, the knowledge of EFL classroom interaction is illustrated in details. Its essence and component parts are explained and introduced comprehensively and deeply.
\end{abstract}

Keywords: knowledge, EFL classroom, interaction, essence, component

\section{Introduction}

As Allwright (1984) suggested, interaction was the fundamental fact of L2 classroom. Further, in EFL (English as a Foreign Language) classroom, interaction carries two roles: the object of teaching and the carrier of teaching, while in other subject classroom it just carries the role of the latter. Interaction is hence more important in EFL classroom than that in other subject classrooms. Possessing Classroom Interactional Competence (Walsh, 2006, p. 130) becomes one essential language capability for a TEFL (Teaching English as a Foreign Language) teacher. In TEFL teacher education, classroom interaction is important (Yang Xueyan, 2003). At the beginning, teachers learn to teach by simply modeling master teachers' interaction skills. The teachers must imitate these superficial techniques as much as possible. This kind of learning approach is called "the Craft Model" by Wallace (1991, p. 6). In 1960s and 1970s, it was popular to use multifarious checklists to record excellent teachers' classroom interaction behavior, such as FIAC (Flanders Interaction Analysis Categories), FLINT (Foreign Language INTeraction), COLT (Communication Orientation of Language) and other coding systems. These instruments have a firm root planted in behavior psychology (Walsh, 2006, p. 40). This quantitative description approach is believed the most reliable for teachers to understand classroom interaction and is called "the Applied Science Model" (Wallace, 1991, p. 8), which requires the teachers to analyze interaction problems by using technical rationality and the findings of experiments. The two models see classroom interaction as an objective knowledge. Nowadays, the terms of reflection are popular in TEFL teacher education and development programs (Farrell, 2012). "The Reflective Model" (Wallace, 1991, p. 19) spreads widely in TEFL teacher education. The teachers' comprehension, reasoning, transformation and reflection are emphasized (Shulman, 1987). In this case, the understanding on TEFL classroom interaction changes a lot. This article aims to elucidate these changes and construct a framework of knowledge of EFL classroom interaction in teacher education.

\section{Defining Classroom Interaction in "The Reflective Model" Teacher Education}

Here, the meaning of classroom interaction is limited to verbal communication in classroom. In "the reflective model", the teacher's status is elevated and personal theories are accepted legitimate (Freeman \& Johnson, 1998). Classroom interaction, as one fact of L2 classroom, is closely linked to EFL teachers (Allwright, 1984). Further, Zou Weicheng (2009) claimed that "in EFL classroom, the teacher should learn how to negotiate meaning with the students and this kind of capability was a distinct knowledge that is specific to EFL teaching" (p.44). Therefore, classroom interaction should be focused in EFL teacher education. Nevertheless, even though teachers know it and try best to interact with students in the classroom, the quality and the amount of classroom interaction appeared are found limited (e.g., Bot, 2001; Hermans-Nymark, 2007). What's more, there is a separation between advocacy of the policymakers and the teachers' act of teaching. Take TEFL teacher education in China for example. The latest National Curriculum Standards (2012) makes it clear that 
"The teacher should provide students with many chances to use English in the classroom ..., create conditions for them to explore topics that they are interested in ..." (New National Curriculum Standards for Senior English, 2012, p. 15)

"The task designed should stimulate the students to use language ..." (New National Curriculum Standards for Senior English, 2012, p. 17)

From these statements, it is clear that education policy emphasizes classroom interaction. With policy support, teachers should have enough courage to challenge traditional transmission-based instructional practices. However, in teaching act, a few teachers mention two-way interaction (Liu Xuehui, 2005; Pei Xuemei \& Li Min, 2006; Guo Xinjie, 2008). There are three kinds of reasons for this phenomenon: capability, willingness, courage (Ouyang, Hu Hua, 2011). The first one is fundamental. With capability, the teacher can choose to interact or not to interact in teaching. In China, as we noticed, the policy provides support for task based teaching, in which interaction is the primary element. So EFL teachers will not fear loathing from the context. Notwithstanding the support of the outsiders and the teachers' own willingness, their capability is rather limited. This can be reflected in sparse presentations in EFL teacher education curriculum design, in which there is no space to introduce the development of researches on classroom interaction. The viewpoints about classroom interaction appear sparsely in the teaching methodology course books, general linguistic course books and in the mentors' or the supervisors' suggestions. Apparently, this phenomenon is unpleasant. It is necessary to consider teachers' capability to challenge traditional transmission-based instructional practices. Without doubt, if they have not clearly understood classroom interaction, how can they improve their interaction? Therefore, it is necessary to clarify what the classroom interaction is in EFL teacher education. Currently, teachers' knowledge is regarded as the basis of teacher professional development (Shulman, 1987), but for EFL teacher education, knowledge of EFL classroom interaction has never been addressed. In this article, classroom interaction is regarded as the knowledge. There are at least two benefits for this new viewpoint.

First, a systematic and precise knowledge can help teachers understand and engage in classroom interaction effectively in short term. If classroom interaction is just sparsely noticed in teacher education, it is not good for teachers to form organized and integrated cognition on interaction.

Second, a systematic and precise knowledge can help teachers understand the relation between interaction and students' learning more clearly. Every research must take some stances, but the introduction of these stances is always omitted on the grounds that in traditional "Craft Model" and "Technical Model" the curriculum courses only provide research products and the teacher has no right to be suspicious of the origins and the progression of the researches. These kinds of introduction view teachers as a blank vessel and deprive teachers of reflecting capability. In "the Reflective Model", teachers can determine which research findings are connected with their students' language development in their classroom themselves (Graves, 2009, p. 120). This respect on teachers' human agency can establish an actual connection between teaching theory and practice.

To define classroom interaction can date back to the literature of EFL teachers' knowledge base.

\section{Literature Review of EFL Teacher's Knowledge}

There are three ways to identify EFL teachers' knowledge: borrowing from general education categories directly; categorizing the knowledge after an empirical research; combining two methods.

Table 1. Typical TEFL teacher's knowledge categories

\begin{tabular}{lll}
\hline Researcher & Categories of TEFL teachers' knowledge base & Method \\
\hline Richards (1998, p. 19) & (1)Theories of teaching & $\begin{array}{l}\text { Combining two } \\
\text { methods }\end{array}$ \\
& $\begin{array}{l}\text { (2)Teaching skills } \\
\text { (3)Communicational skill }\end{array}$ & \\
& (4)Subject matter knowledge & \\
& (5)Personal reasoning & \\
& (6)Decision making & \\
& (7)Contextual knowledge & Empirical study \\
\hline Tsui (2003, pp. & (1)Knowledge of English, & \\
\hline $250-251)$ & &
\end{tabular}


(2)Language pedagogical knowledge

(3)Language learning knowledge

(4)Knowledge of managing learning

(5)Other curriculum knowledge

(6)Knowledge about the learner

\begin{tabular}{lll}
\hline Andrews & (1)TLA(Teacher language awareness) & $\begin{array}{l}\text { Combining two } \\
\text { methods }\end{array}$ \\
(1999, as cited in Zhu & (2)Subject matter cognition & \\
& (3)Knowledge of learners & \\
& (4)Knowledge of curriculum & \\
& (5)Knowledge of pedagogy & \\
& (6)Knowledge of context & Empirical study \\
\hline Gong Yafu (in press) & (1)Subject matter knowledge & \\
& (2)Pedagogical knowledge & \\
& (3)Pedagogical content knowledge \\
& (4)Knowledge of the learners and their characteristics \\
& (5)Knowledge of educational contexts & \\
& (6)Knowledge of the curriculum and educational ends & \\
\hline Han Gang (2011) & (1) Pedagogical knowledge & Empirical study \\
& (2)Theoretical knowledge & \\
& (3)Practical knowledge & \\
& (4)Educational knowledge & \\
\hline
\end{tabular}

The table shows that most of the categorizing method is to infer after an empirical study based on previous knowledge categories, such as Shulman's and Richard's. Of course, Shulman's general teachers' knowledge categorization imprints every knowledge category in this table because he is the first person to systematically propose the knowledge base for teacher education. However, when the knowledge domains of general education go into subject content teaching, it should combine with subject characteristics. So these examples in Table 1 have the generic footprints and the specific ones as well. Viewing from the table, except Andrews' division, most can be used as a reference for other subject discipline teaching. As one representative of EFL teaching policymakers in Chinese mainland, Gong Yafu's knowledge domains need noticing. Nevertheless, his domains have no significance among the five examples, instead, Andrews' (1999) categorization is worth of taking into account. Andrews is the first person to clearly define the special knowledge EFL teachers should have, that is, Teacher Language Awareness. He pointed out "central of these (EFL Teachers') knowledge bases is TLA" (p. 146). This paper admits his idea that there is central knowledge which can distinguish EFL teaching from the other content teaching, and addresses that there is another central knowledge, namely, the knowledge of classroom interaction in EFL teachers' knowledge base.

Classroom interaction is regarded as a pedagogical instrument in mathematics teaching (Radford, 2011), which can help the teacher to create conditions for learning to occur. In EFL teaching, classroom interaction is paid much more attention because it is not merely a tool in which learning appears, but also language teaching and learning objectives. In EFL teacher education, some scholars confirm explicitly that classroom interaction is important. For example, Zou Weicheng (2009) posits that in EFL classroom, the teacher should learn to create, elicit and use learning conditions and when these learning conditions appear, he or she should negotiate meaning with the students in accordance with their language competence (p. 44). It is no doubt that these conditions should be established in classroom interaction. Zou Weicheng also claims that this kind of teacher's capability is a kind of knowledge that is specific to EFL teachers (p. 44). It is assured that interaction is of high status in EFL teacher education, but the knowledge about it has not been defined.

\section{Defining "Knowledge" and "The Knowledge of EFL Classroom Interaction"}

For teachers, sparse knowledge on classroom interaction is not enough for planning satisfactory tasks or 
activities, engaging in teaching successfully and reflecting on teaching efficiently. It is inconsistent between many advocacies to emphasize interaction in research field and the loose operation in teacher education. Therefore, it is necessary to construct a systematic knowledge on EFL classroom interaction.

The first thing is to define the connotation of "knowledge". Owing to the influences from the debates in the research paradigms of social science, the connotation of "knowledge" has been argued constantly. The technocratic paradigm holds that "knowledge" is fixed, stable and can be transmitted while the humanism paradigm holds that "knowledge" is flexible and can merely be transformed. This debate impacts the connotation of the knowledge foundation in teacher education. In earlier days, teacher education was influenced seriously by the technocratic paradigm. "Knowledge" in teacher education was viewed a technical formula outside the teachers. The researchers produce teaching knowledge and the teachers receive and consume these knowledge. Shon (1987) criticizes this opinion by saying that the professional often falls into uncertain environment and the fixed knowledge cannot help the teacher in this situation. Elliot (1991) makes a further call that "knowledge foundation" should shift to "practical turn" (as cited in Lin Yigang, 2009, p. 67). A summary reflects the three stages of the development of "knowledge" connotation in teacher education clearly:

The first stage: what the teacher should know?

The second stage: what the teacher knows?

The third stage: what knowledge the teacher knows in teaching?

(Lin Yigang, 2009, p. 17)

Although the third view is popular currently, the first and the second view is still essential for teacher education. The knowledge of classroom interaction is based on all of them, that is, what the teacher should know about EFL classroom interaction; what the teacher knows about EFL classroom interaction; what knowledge the teacher knows in EFL classroom interaction.

\section{Constructing the Knowledge of EFL Classroom Interaction}

\subsection{The Essence of the Knowledge of EFL Classroom Interaction}

There are two noteworthy points on the essence about the knowledge of EFL classroom interaction. First, it is fixed and flexible as well, so it can be acquired explicitly and understood tacitly. Second, it is a product and a process as well, so it can be achieved in formal instruction and informal contact such as in action researches, exploratory practice and reflective teaching as well. As abovementioned, the knowledge of classroom interaction should be understood on three aspects.

What the teacher should know about classroom interaction includes all the achievements all the connected researches have got. Currently, the researches on interaction can be divided into two categories: classroom situation and social situation. Based on classroom situation, interaction has specific teaching aim. For example, the researches on input, output and interaction is closely linked to promoting students learning, which is the final teaching aim of EFL teaching. Because the classroom is a part of society, classroom is a social context (Walsh, 2006, p. 62), namely, a part of everyday life. CA (Conversation analysis), a theory about the rules in everyday conversation, is in relevance to classroom interaction.

What the teacher knows about classroom interaction includes personal views on interaction. Because teaching is often be influenced by the teacher's experience, belief, and other individual factors (Graves, 2009, p. 118), he or she may have established some schemata on interaction when engaging in teaching. These schemata might be explicit and implicit as well.

What the teacher appears to know includes not only the rigorous public knowledge on classroom interaction, but also what the teacher knows in teaching. In some cases, what the teacher declares to know is in conflict with their action in the class (Polio \& Duff, 1994). This conflict requires the teachers' declaration should be identified discreetly.

\subsection{The Components of the Knowledge of EFL Classroom Interaction}

As mentioned earlier, the knowledge of EFL classroom interaction has three sources: what the teacher should know; what the teacher knows; what the teacher appears to know. Bases on these sources, the components of the knowledge of EFL classroom interaction can be summarized as follows. 


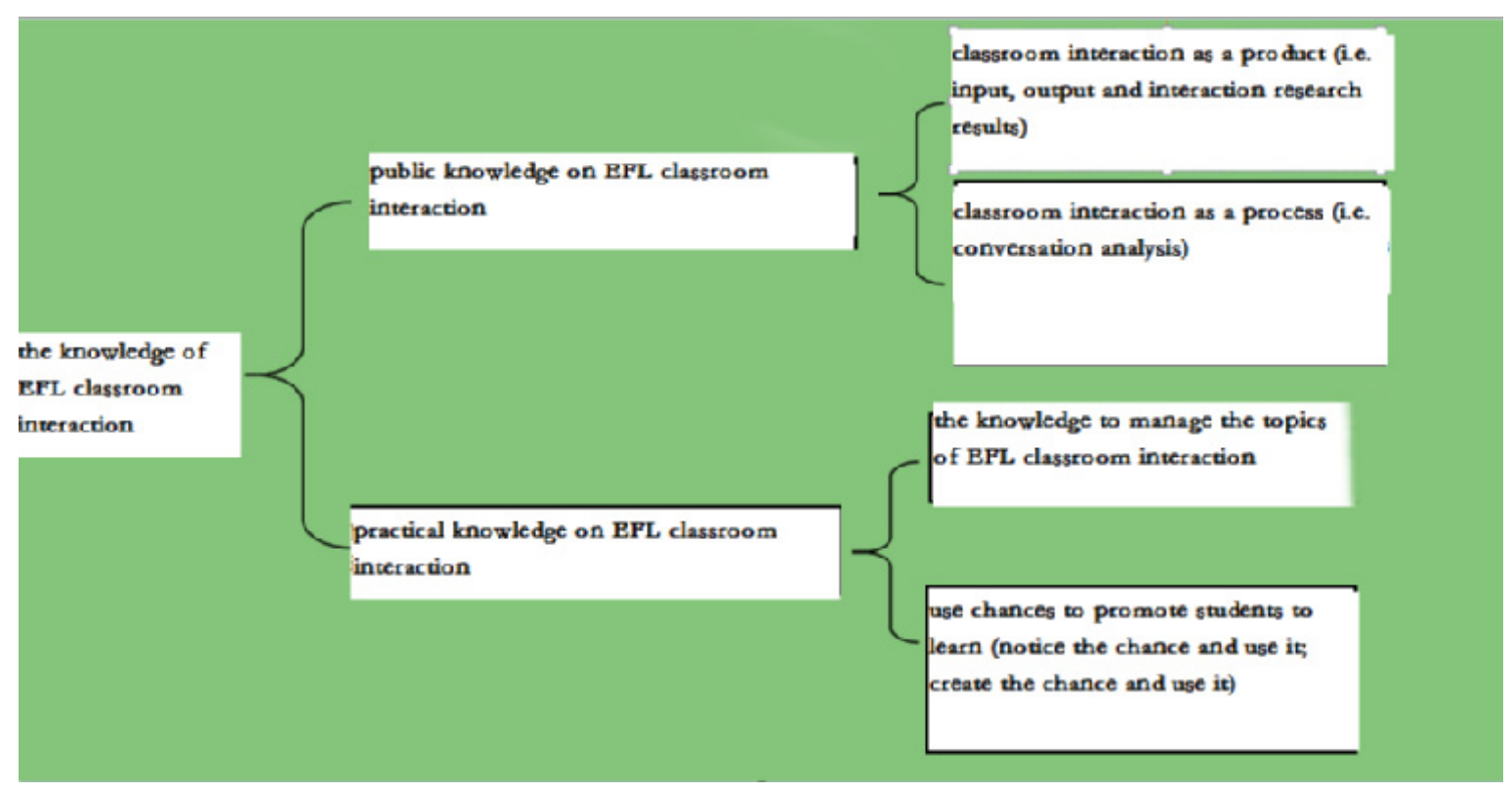

Figure 1. The components of the knowledge of EFL classroom interaction

As shown in this figure, the knowledge of EFL classroom interaction can be divided into two categories: public knowledge and practical knowledge on EFL classroom interaction. Public knowledge originates from two aspects: classroom interaction as a product and as a process. If it is regarded as a product, input, output and interaction's research findings are typical because these achievements often explores the relationship between certain interaction behavior and students learning. If it is regarded as a process, the success of students learning does not exist in certain interaction behavior, but in flowing talk. Moreover, the former dwells into the product-oriented education paradigm and concerns with classroom context, while the latter dwells into the process-oriented education paradigm and is about interaction in everyday life. The abovementioned has explained that the classroom is a social context; classroom interaction carries the characteristic of everyday conversation on one hand. For subject teaching, classroom interaction should embody specific teaching aims on the other hand.

\subsection{Public Knowledge on EFL Classroom Interaction}

Classroom interaction can be seen as behavior as well as process. These views are all acceptable in public. As behavior, there are many forms of interaction, such as questions (Thompson, 1997). It is often understood as a teaching skill. For example, teachers' language modification strategies are useful for students' learning. As process, it is regarded as a pedagogical instrument (Radford, 2011), functions of language form (Zhao Fei \& Zou Weicheng, 2009) or process of realizing specific teaching aims (Yang Xueyan, 2003). In this case, the teachers' competences depend on their wisdom in action. For example, questions have received attention in studies of classroom interaction (Thompson, 1997) and display questions are often be seen as ineffective variable for second language acquisition (Lee, 2006), but if they are made intelligibly, it can also promote students' learning (Lee, 2006).

As for public knowledge, SLA plays an important role. In fact, the close connection between SLA theories and teaching practice was established from the start (Ellis, 2010). Ellis (2009) suggests that "SLA is best viewed as a body of technical knowledge that can illuminate pedagogically inspired questions" (p. 141). Although most of SLA theories are addressed by speculating, "the likelihood of different aspects of interaction creating the conditions needed for acquisition to occur." (Ellis, 2012, p. 15). Here, take input, output and interaction researches for example. These researches are central points in SLA technical knowledge and are related to second language pedagogy closely. Although some concerned empirical researches' findings are various on the relation between SLA and stents learning, scholars are consensus on the following items.

1. It is useful that SL/FL learners receive the target language as much as possible (based on Input Hypothesis).

2. It is useful that SL/FL learners use the target language as much as possible (based on Output Hypothesis).

3. It is useful that SL/FL learners engage in classroom interaction, especially when interacting with the teacher 
(based on Interaction Hypothesis).

Apparently, these rules discuss SL/FL language learning from the students' perspective. In teacher education, this perspective should shift to the teachers, who need to know how these rules are in relevance with their teaching. In other words, they should know

1. How to provide the students with target language as much as possible.

2. How to promote the students to use the target language.

3. How to stimulate the students to engage in classroom interaction.

There are many findings for these questions in SLA field.

1. The teacher can use eight interactional structure of conversation to promote students learning: conversational frames, confirmation checks, clarification checks, self-repetitions, other-repetitions, expansions, and many other skills (Long, 1983).

2. The teacher should provide comprehended input (Gass, 1997).

3. The teacher should attract students' attention initially, then promote them to intake and use it, at last they will acquire the target language (Gass, 1997).

4. The teacher should mention time, opportunities, sociocultural context, attract students' attention, try best to promote students to use the target language (Gass, 2010, p. 216).

The first is Interactional Hypothesis proposed by Long, on which the next three built up by absorbing other research achievements. These rules are on the traditional SLA research base-Cognition Theory. In recent years, sociocultural theories influenced SLA. They put forward many completely different ideas on the efficiency of classroom interaction. The forth item, Gass's model of the Relation between Input and Output, is an example influenced deeply by sociocultural theories. The researches on input, output and interaction in SLA, however, still exist in language evidences in most cases, not in social context (Zhao Fei \& Zou Weicheng, 2009). In this case, CA-for-SLA appears because CA represents EFL teaching and learning in a specific context.

The foundation of CA depends on at least two assumptions.

1. Interaction is organized.

2. Contributions to interaction are contextually.

(as cited in Heritage, 1984, p. 241)

In other words, there is emerging grammar of interaction (Markee, 2008) in the light of CA. From the perspective of grammar, some laws exist in the interaction. Schegloff, Sacks, and many other scholars have gained many achievements on these respects. For example, they find out "cut-offs are generally post-positioned with respect to trouble source" (Schegloff, 1979, as in cited in Markee, 2008, p. 404). The basic unit of conversation analysis is "turn" in conversation. Until now, the researches on TCU (Turn-Allocation Techniques), AP (Adjacency Pair), and repair have achieved a lot. For TEFL teachers, it is necessary to know the abovementioned knowledge.

The public knowledge about the laws in everyday conversation and on input, output and interaction are all technical knowledge for EFL teachers. However, important to note is that it is the teacher who conceptualizes and experiences such knowledge in practice. This is related to the practical knowledge on EFL classroom interaction.

\subsection{Practical Knowledge on EFL Classroom Interaction}

The components of practical knowledge can be divided into two main parts: topic management and learning opportunities. Topic is an influential factor for students learning. For the topic, the person will get more chances to participate in the learning activity if he or she devises it. If the student gets partial control over the topic, there are some advantages (Kumaravadivelu, 2011, p. 30).

1. In the tailoring of the linguistic complexity of the input to the learner's own level.

2. In the creating better opportunities for negotiating meaning when communication problem arises.

3. In the stimulation of more extensive and more complex production of language on the part of the learners.

However, owing to the specific teaching aim, the topic cannot be controlled by the students all the time. Allowing the students partially control topics does not mean the teacher can put aside their responsibilities in the classroom. Therefore, Kumaravadivelu (2011) points out that the teacher should "manage skillful the hot button 
the student arises" (p. 30). In other words, the teacher should be able to manage the topic, such as by designing a task with a topic based on the teaching aim.

Learning opportunities exist in the classroom interaction. Richards (1998) declares clearly that "without communication, teaching and learning would be impossible" (p. 6). For the teacher, he or she should seek, elicit, create and use every chance to promote students to learn. For students, they should accept these learning opportunities and study actively and diligently. The teacher, with responsibilities to promote students learning, should be aware of learning opportunities (Walsh, 2003). In this case, public knowledge may assist the teacher. For instance, Comprehended Input is one typical public theory and requires the teacher to negotiate meaning with the student. Reminding the students of noticing the communication obstacles and providing enough repetitions of knowledge about language, the teacher and students can collaborate well to realize the teaching aim in interaction. Many other suggestions have been made in Walsh's (2006) monograph Investigating Classroom Discourse on creating learning opportunities. However, public knowledge on interaction merely occupies a small percentage (Graves, 2009, p. 118). One important thing is that the teacher should be good at learning to teach. Reflective teaching and exploratory teaching are good ways for them to construct the knowledge on EFL classroom interaction in teaching.

\section{Conclusion}

This article briefly introduces another central knowledge an EFL teacher should have: the knowledge of EFL classroom interaction. Because interaction carries more meanings in EFL classroom than that of other content classroom, EFL teacher education should focus enough attention on it. The knowledge of EFL classroom interaction is consisted of two parts: public knowledge and practical knowledge. Research findings on the former are fruitful and developing, such as Input Hypothesis, Output Hypothesis and Interaction Hypothesis. Recently, sociocultural theories have come into SLA, which broaden the scope and depth of the researches on classroom interaction. The latter mainly depends on the teachers themselves and teacher educators' assistance. On the way to professional development, the teacher should reflect and explore constantly on their classroom interaction. To sum, the knowledge of EFL classroom interaction is dynamic, which requires the teacher to inquiry actively and deeply with scientific attitude.

\section{References}

Allwright, R. (1984). The importance of interaction in classroom language learning. Applied Linguistics, 5(2), 156-171. http://dx.doi.org/ 10.1093/applin/5.2.156

Andrews, S. (1999). Teacher Language Awareness. Cambridge: Cambridge Press. http://dx.doi.org/10.1080/09658419908667125

Bot, K. D. (2001). Interaction in the classroom. TESOL Quarterly, 35(4), 602-603. http://dx.doi.org/10.2307/3588434

Education Ministry. (2012, pilot version). New national curriculum standards for senior English. Retrieved from http://wenku.baidu.com/view/7ea6783443323968011c9253.html

Education Ministry. (2012, pilot version). New national curriculum standards for senior English. Retrieved from http://wenku.baidu.com/view/7ea6783443323968011c9253.html

Ellis, R. (2009). SLA and teacher education. In A. Burns, \& J. C. Richards (Eds.), The Cambridge Guide to Second Language Teacher Education. Cambridge: Cambridge University Press.

Ellis, R. (2010). Second language acquisition, teacher education and language pedagogy. Language Teaching, 43(2), 182-201. http://dx.doi.org/10.1017/S0261444809990139

Ellis, R. (2012). Language teaching research and language pedagogy. Oxford: Wiley-Blackwell. http://dx.doi.org/10.1002/9781118271643

Farrell, T. S. C. (2012). Reflecting on reflective practice: (Re)visiting Dewey and Schon. TESOL Journal, 3(1), 7-16. http://dx.doi.org/10.1002/tesj.10

Freeman, D., \& Johnson, K. E. (1998). Reconceptualizing the knowledge - base of language teacher education. TESOL Quarterly, 32(3), 397-417. http://dx.doi.org/10.2307/3588114

Gass, S. (2010). The relationship between L2 input and L2 output. In E. Macaro (Ed.), The Continuum Companion to SLA (pp. 194-219). New York NY: Continuum.

Gong, Y.-F. (in press). STEPSS - Standards for teachers of English in primary and secondary schools. Retrieved September 10, 2013, from http://wenku.baidu.com/view/7c8204210722192e4536f699.html 
Graves, K. (2009). The curriculum of second language teacher education. In A. Burns, \& J. C. Richards (Eds.), The Cambridge Guide to Second Language Teacher Education (pp. 115-125). Cambridge: Cambridge University Press.

Han, G. (2011). Constructing Pedagogical Content Knowledge for EFL Teachers. Shanghai: Shanghai Foreign Language Education Press.

Heritage, J. (1984). A change-of-state token and aspects of its sequential placement. In J. Heritage (Ed.), Structures of Social Action: Studies in conversation analysis (pp. 299-345). Cambridge: Cambridge University Press.

Hermans-Nymark, L. (2007). English in the EFL classroom: Why not? Classroom discourse patterns and teachers' belief (Doctoral dissertation, Radboud University, Nijmegen, Netherland). Retrieved from http://repository.ubn.ru.nl/handle/2066/29803

Kumaravadivalu, B. (2011). Language Teacher Education for a Global Society: A modular model for knowing, analyzing, recognizing, doing, and seeing. New York NY: Routledge.

Lee, Y. A. (2006). Respecifying display questions: Interactional resources for language teaching. TESOL Quarterly, 40(4), 691-713. http://dx.doi.org/10.2307/40264304

Lin, Y.-G. (2009). A Case Study of Teachers' Knowledge Development in China Mainland. Shanghai: Xuelin Press.

Liu, Y.-Q. (2009). On teacher's knowledge. In W. C. Zou (Ed.), The Research of Chinese Fundamental English Teacher Education (pp. 119-130). Shanghai: East China Normal University Press.

Long, M. (1983). Native speaker/non-native speaker conversation and the negotiation of comprehensible input. Applied Linguistics, 4(2), 126-141. http://dx.doi.org/10.1093/applin/4.2.126

Markee, N. (2008). Toward a learning behavior tracking methodology for CA-for-SLA. Applied Linguistics, 29 (2008), 404-427. http://dx.doi.org/10.1093/applin/amm052

Ouyang, H.-H. (2011). From "can" to "would" and "dare to"-an exploration of teacher development on local routine China. In Wu Yi-An, \& Zhang Lian (Eds.), Cultural construction and teacher development of foreign language teachers (pp. 46-55). Beijing: Foreign Language Teaching and Research Press.

Polio, C. G., \& Duff, P. A. (1994). Teachers' language use in university foreign language classrooms: A qualitative analysis of English and target language alternation. The Modern Language Journal, 78(3), 313-326. http://dx.doi.org/10.1111/j.1540-4781.1994.tb02045.x

Radford, L. (2011). Classroom interaction: Why is it good? Educational Studies Mathematics, 76, 101-115. http://dx.doi.org/10.1007/s10649-010-9271-4

Richards, J. C. (1998). Beyond Training. Cambridge: Cambridge University Press.

Richards, J. C. (2011). Competence and performance in language teaching. In Wu Yi-An, \& Zhang Lian (Eds.), Cultural Construction and Teacher Development of Foreign Language Teachers (pp. 16-46). Beijing: Foreign Language Teaching and Research Press.

Shon, D. (1987). Educating the Reflective Practitioner: Toward a new design for teaching and learning in the professions. Oxford: Jossey-Bass Inc Pub

Shulman, L. S. (1987). Knowledge and teaching: Foundations of the new reform. Harvard Educational Review, $57(1), 1-22$.

Thompson, G. (1997). Training teachers to ask questions. ELT Journal, 51(2), 99-105. http://dx.doi.org/10.1093/elt/51.2.99

Tsui, A. B. M. (2003). Understanding Expertise in Teaching. New York, NY: Cambridge University Press. http://dx.doi.org/10.1017/CBO9781139524698

Wallace, M. J. (1991). Training Foreign Language Teacher. Cambridge: Cambridge University Press.

Walsh, S. (2003). Developing interactional awareness in the second language classroom through teacher self-evaluation. Language Awareness, 12(2), 124-142. http://dx.doi.org/10.1080/09658410308667071

Walsh, S. (2006). Investigating the Classroom Discourse. New York, NY: Routledge.

Woods, D. (1996). Teacher Cognition in Language Teaching: Belief, decision-making and classroom practice. Cambridge: Cambridge University Press. 
Yang, X.-Y. (2003). The review of western researches on foreign language classroom interaction. Foreign Language Teaching, 1, 51-62.

Zhao, F., \& Zou, W.-C. (2009). On the theorization of the interaction hypothesis. Foreign Language Teaching and Practice, 2, 78-87.

Zhu, X.-Y. (2004). The Development of Pedagogical Content Knowledge in Novice Secondary School Teachers of English. Nan Jing: Nan Jing University Press.

Zou, W.-C. (2009). The report on pre-service foreign language teacher education on fundamental education stage. In Zou Weicheng (Ed.), The Research of Chinese Fundamental English Teacher Education (pp. 31-76). Shanghai: East China Normal University Press.

\section{Copyrights}

Copyright for this article is retained by the author(s), with first publication rights granted to the journal.

This is an open-access article distributed under the terms and conditions of the Creative Commons Attribution license (http://creativecommons.org/licenses/by/3.0/). 